\title{
Identifikasi Penyebab ADR (Adverse Drug Reactions) pada Pasien CHF (Congestive Heart Failure)
}

\section{Depi Yuliana, Putri Ramdaniah, *Faizul Bayani, Dedent Eka Bimmaharyanto S., Dita Marina Lupitaningrum}

Program Studi Farmasi, Fakultas Kesehatan, Universitas Qamarul Huda Badaruddin Bagu, Jl. H. Badaruddin Bagu 83562, Indonesia

*Corresponding Author Email: faizulbayani@uniqhba.ac.id

\author{
Sejarah Artikel \\ Dikirim: April 2021 \\ Diterima: May 2021 \\ Dipublikasi: June 2021
}

\section{Kata Kunci}

ADRs; Congestive Heart Failure; WHO-UMC

\begin{abstract}
Abstrak
Congestive Heart Failure (CHF) adalah salah satu masalah kesehatan yang progresif dengan angka mortalitas maupun morbiditas yang tinggi dan berpotensi terjadi ADRs (adverse drug reactions). Resiko ADRs pada pasien $\mathrm{CHF}$ berkaitan dengan regimen obat yang kompleks dan banyaknya komorbiditas pada pasien tersebut. Penelitian ini dilakukan untuk mengukur kausalitas dan menganalisis obat dan jenis ADRs yang paling sering terjadi. Penelitian ini termasuk retrospective study dengan data penelitian yang digunakan adalah data pasien $\mathrm{CHF}$ yang menjalani rawat inap RSUD Provinsi NTB dari tahun 2017 sampai 2019. Penilaian kausalitas ADRs menggunnakan skala WHO-UMC. Data pasien CHF yang digunakan dalam penelitian ini sebanyak 325 pasien. Sebanyak 223 pasien $(68,6 \%)$ tercatat mengalami ADRs dengan hasil penilaian kausalitas menggunakan WHOUMC antara lain $8(1,8 \%)$ certain, 178 (39,9\%) probable/likely, dan 260 $(58,3 \%)$ possible. Obat yang paling banyak menimbulkan ADRs dengan status kausalitas certain adalah ramipril yang menimbulkan batuk. Kesimpulan: sebagian besar ADRs yang terjadi pada pasien $\mathrm{CHF}$ adalah possible dan jenis obat yang paling tinggi menimbulkan ADRs adalah ramipril sehingga penggunaan ramipril perlu lebih diperhatikan karena termasuk highly probable dalam menimbulkan ADRs.
\end{abstract}

\section{Identification of The Causality of ADR (Adverse Drug Reactions) in CHF (Congestive Heart Failure) Patients}

\section{Article History}

Received: April 2021

Accepted: May 2021

Published: June 2021

Key Words

ADRs; Congestive Heart

Failure; WHO-UMC

How to cite this article?

\begin{abstract}
Congestive Heart Failure (CHF) is a progressive health problem with high mortality and morbidity rates and the potential for ADRs (adverse drug reactions). The risk of $A D R s$ in CHF patients is related to the complex drug regimen and the many comorbidities in these patients. This study was conducted to measure causality and analyze the most common drugs and types of ADRs. This study includes a retrospective study with the research data used is data on CHF patients who underwent hospitalization at the NTB Provincial Hospital from 2017 to 2019. The causality assessment of ADRs used the WHO-UMC scale. Data on CHF patients used in this study were 325 patients. A total of 223 patients (68.6\%) were recorded to have ADRs with the results of a causality assessment using WHO-UMC including 8 (1.8\%) certain, 178 (39.9\%) probable/likely, and 260 (58.3\%) possible. The drug that causes the most ADRs with certain causality status is ramipril which causes coughing. Conclusion: most of the ADRs that occur in CHF patients are possible and the type of drug that causes the highest ADRs is ramipril so that the use of ramipril needs to be paid more attention because it is highly probable in causing ADRs.
\end{abstract}

Yuliana, D., Ramdaniah, P., Bayani, F., Bimmaharyanto S., D., \& Lupitaningrum, D. (2021). Identifikasi Penyebab ADR (Adverse Drug Reactions) pada Pasien CHF (Congestive Heart Failure). Lensa: Jurnal Kependidikan Fisika, 9(1), 65-72. doi:https://doi.org/10.33394/j$\underline{1 \mathrm{kf} . v 9 \mathrm{i} 1.4264}$ 


\section{PENDAHULUAN}

Efek samping obat atau ADRs adalah respon terhadap suatu obat yang merugikan ataupun tidak diinginkan dan terjadi pada dosis yang biasanya digunakan pada manusia untuk pencegahan, diagnosis, terapi penyakit atau untuk modifikasi fungsi fisiologik (BPOM RI, 2011; Wadhwa, El Sheikh, \& Rao, 2018). Reaksi obat yang merugikan atau adverse drug reactions (ADRs) merupakan salah satu masalah utama dalam sistem pelayanan kesehatan (Wadhwa et al., 2018). Masalah ADRs ini perlu mendapatkan perhatian karena dapat menyebabkan penurunan kualitas hidup, peningkatan kunjungan ke dokter, perawatan di rumah sakit, bahkan kematian (Ponnusankar, Tejaswini, \& Chaitanya, 2015). Dalam survei lain, Byrne et al. (2006) menemukan bahwa 85\% responden dinyatakan berhubungan dengan setidaknya satu masalah terkait obat, seperti interaksi obat, mengalami efek samping yang berbahaya dari suatu obat, atau menerima obat yang salah (Alomar, 2014). Terlebih pada kasus penyakit yang mempunyai angka mortalitas dan morbiditas yang tinggi, seperti gagal jantung (PERKI, 2015).

Gagal jantung kongestif adalah sindrom klinis progresif yang disebabkan oleh ketidakmampuan jantung dalam memompa darah untuk memenuhi kebutuhan metabolisme tubuh (Wells, Dipiro, Schwinghammer, \& Dipiro, 2015). Gagal jantung adalah sindrom yang umum, membutuhkan biaya yang mahal dan dapat menyebabkan kelemahan bagi pasienn yang dikaitkan dengan rejimen obat yang sangat kompleks dan banyaknya komorbiditas (Wankhede, Pardeshi, Ghorpade, \& Ghongane, 2018)

Obat-obat yang digunakan untuk penatalaksanaan penyakit kardiovaskular tidak serta merta tanpa efek samping, tetapi justru dapat menyebabkan konsekuensi yang merugikan jika tidak dipantau dengan benar. Meningkatnya jumlah obat pada pasien jantung menimbulkan adanya kecenderungan untuk menyebabkan masalah terkait obat seperti ADRs, interaksi obat antar obat, dll. Obat kardiovaskular dilaporkan menyumbang 9\% dari kunjungan ke pelayan kesehatan terkait pengobatan. Satu dari setiap lima pasien jantung diketahui mengalami ADRs dan 17,9\% di antaranya dapat dicegah, yang kemudian membutuhkan pemantauan dan pelaporan yang intensif (Wadhwa et al., 2018). Banyak bukti menunjukkan bahwa sebenarnya efek samping obat dapat dicegah, dengan pengetahuan yang bertambah, antara lain diperoleh dari kegiatan pemantauan aspek keamanan obat pasca pemasaran. Oleh karena itu, kegiatan ini menjadi salah satu komponen penting dalam sistem regulasi obat, praktik klinik dan kesehatan masyarakat secara umum (BPOM RI, 2011)

Adanya pertimbangan penyakit kardiovaskular sebagai salah satu masalah utama kesehatan, potensi timbulnya ADRs pada obat-obat kardiovaskular serta keterbatasan dalam uji pra-pemasaran untuk evaluasi keamanan obat, menjadi alasan diperlukannya evaluasi ADRs yang diinduksi oleh obat tersebut.

Pada penelitian ini akan dilakukan pengukuran kausalitas ADRs menggunakan skala WHO-UMC, menentukan tingkat keparahan ADRs pasien CHF menggunakan skala Hatwig \& Siegel, serta menganalisis obat dan jenis ADRs yang paling sering terjadi.

\section{METODE}

Penelitian ini merupakan penelitian kuantitatif retrospektif. Populasi penelitian ini adalah semua pasien CHF (Congestive Heart Failure) yang berusia lebih dari 20 tahun yang menjalani rawat inap di RSUD Provinsi NTB pada periode tahun 2017 sampai 2019, yaitu sebanyak 1392 pasien. Sampel pada penelitian ini adalah data pasien dengan diagnosa utama $\mathrm{CHF}$ di ruang rawat inap RSUD Provinsi NTB dan telah mengkonsumsi obat $\mathrm{CHF}$ minimal 4 minggu berdasarkan data rekam medis, yaitu sebanyak 325 pasien. Data penelitian diperoleh dari catatan pada rekam medis pasien rawat inap RSUD Provinsi NTB. Penilaian kausalitas ADRs disini menggunakan WHO-UMC. Pasien dengan 
penyakit komorbiditas dan pasien yang menggunakan obat selain obat CHF tetap dimasukkan menjadi sampel. Namun, dalam penilaian ADRs faktor penyakit dan obat lain tetap dikaji agar hasil penilaian kausalitas ADRs lebih valid.

Instrumen dalam penelitian ini adalah lembar pengambilan data pasien, lembar evaluasi ADRs berdasarkan WHO-UMC. Lembar pengambilan data pasien memuat identitas pasien, riwayat penggunaan obat, dan data subjektif maupun objektif. Pengisian lembar tersebut berdasarkan data-data yang diperoleh pada rekam medis, berupa keluhankeluhan pasien dan data hasil pemeriksaan laboratorium yang dicurigai sebagai manifestasi klinik dari ADRs. Pengumpulan data pada penelitian ini dilakukan dengan melakukan penelusuran catatan rekam medis pasien untuk memilih pasien yang memenuhi kriteria dan data yang tertera pada rekam medis menjadi dasar untuk mengisi lembar penelusuran data pasien, lembar evaluasi ADRs maupun lembar penilaian tingkat keparahan ADRs. Analisis data dilakukan dengan bantuan SPSS (Statistical Package for Social Science) dan Microsoft Excel.

\section{HASIL DAN PEMBAHASAN}

Karakteristik Pasien CHF (Congestive Heart Failure) yang terlibat sebagai responden disajikan pada Tabel 1. Karakteristik pasien dalam penelitian dikelompokkan berdasarkan jenis kelamin, umur, ada tidaknya penyakit komorbiditas dan stage CHF. Data karakteristik pasien CHF sebagai responden penelitian dapat dilihat pada Tabel 1. Dalam penelitian ini, pasien dengan jenis kelamin laki-laki (58\%) lebih banyak dibanding perempuan (42\%) dan pasien dengan dengan kategori dewasa (20 - 60 tahun) sebanyak $56 \%$, lebih banyak dibandingkan pasien lansia yaitu 44\%. Beberapa penelitian yang lain juga menunjukkan hasil yang sama (Mehta \& Cowie, 2006; Razzolini \& Lin, 2015). Begitu pula data pada profil penyakit tidak menular tahun 2016 menunjukkan bahwa jumlah kasus dengan diagnosis gagal jantung yang menjalani rawat inap di Rumah Sakit di Indonesia (SIRS 2015) lebih banyak pada pasien laki-laki dibandingkan pasien perempuan, dan pasien dengan kasus gagal jantung terbanyak terjadi pada kelompok usia 45-64 tahun (Kemenkes.RI, 2016).

Tabel 1. Karakteristik Pasien CHF (Congestive Heart Failure) sebagai Responden

\begin{tabular}{lcc}
\hline Karakteristik Pasien & Jumlah Pasien (N=325) & Persentase (\%) \\
\hline Jenis Kelamin & & \\
\hline Laki-laki & 190 & $58,5 \%$ \\
Perempuan & 135 & $41,5 \%$ \\
\hline Umur & & \\
\hline $20-60$ & 181 & $55,7 \%$ \\
$>60$ & 144 & $44,3 \%$ \\
\hline Komorbiditas & & \\
\hline Tidak & 37 & $11,4 \%$ \\
Ya & 288 & $88,6 \%$ \\
Stage & & \\
\hline Tidak ada Keterangan & 220 & $67,7 \%$ \\
1 & 10 & $3,1 \%$ \\
2 & 35 & $10,8 \%$ \\
3 & 34 & $10,5 \%$ \\
4 & 26 & $8,0 \%$ \\
\hline
\end{tabular}


Pada Tabel 1 terlihat bahwa pasien dengan komorbiditas menunjukkkan prevalensi lebih tinggi $(88,6 \%)$ daripada pasien tanpa komorbiditas (11,4\%). Adanya informasi mengenai komorbiditas (penyakit penyerta) pada pasien $\mathrm{CHF}$ adalah hal yang penting, sebab komorbiditas dapat mempengaruhi pengobatan CHF itu sendiri, bahkan terapi untuk penyakit komorbiditas dapat memperburuk gejala dan kondisi gagal jantung (misalnya penggunaan NSAID), dan obat yang digunakan untuk CHF maupun untuk penyakit penyerta dapat saling berinteraksi (PERKI, 2015). Klasifikasi yang digunakan untuk menilai seberapa berat penyakit $\mathrm{CHF}$ pada penelitian ini disesuaikan dengan dengan klasifikasi yang digunakan oleh rumah sakit sebagai tempat penelitian, yaitu berdasarkan gejala yang berkaitan dengan kapasitas fungsional sesuai dengan kriteria pada NYHA (New York Heart Association). Pada Tabel 1, sebagian besar $(67,7 \%)$ data pasien justru tidak dilengkapi dengan keterangan stage $\mathrm{CHF}$ pasien. Kemungkinan hal ini dikarenakan tidak semua dokter jantung yang menangani pasien $\mathrm{CHF}$ di rumah sakit tersebut terbiasa mencantumkan stage pasien pada catatan rekam medis.

Tabel 2. Hasil Penilaian Kausalitas WHO-UMC pada Pasien CHF (Congestive Heart Failure) RSUD Provinsi NTB

\begin{tabular}{lcc}
\hline WHO-UMC & Angka Kejadian ADRs (N = 446) & Persentase (\%) \\
\hline Certain & 8 & $(1,8 \%)$ \\
Probable/Likely & 178 & $(39,9 \%)$ \\
Possible & 260 & $(58,3 \%)$ \\
\hline
\end{tabular}

Tabel 3. Manifestasi Klinik ADRs (Adverse Drug Reactions) pada Pasien CHF (Congestive Heart Failure) RSUD Provinsi NTB

\begin{tabular}{|c|c|c|c|}
\hline Manifestasi Klinik ADRs & Jenis Obat & N (416) & Persentase \\
\hline Peningkatan kreatinin & $\begin{array}{l}\text { Furosemid, Lisinopril, } \\
\text { Spironolakton, Candesartan, } \\
\text { Ramipril, Valsartan }\end{array}$ & 66 & $15.9 \%$ \\
\hline Batuk & - Ramipril, Lisinopril & 72 & $17.3 \%$ \\
\hline Pusing & $\begin{array}{l}\text { - Lisinopril, Ramipril, } \\
\text { Bisoprolol, Carvedilol, } \\
\text { Valsartan }\end{array}$ & 61 & $14.7 \%$ \\
\hline Nyeri perut & $\begin{array}{l}\text { - Bisoprolol, Ramipril, } \\
\text { Lisinopril, Furosemid, } \\
\text { Spironolakton }\end{array}$ & 34 & $8.2 \%$ \\
\hline Kelelahan & - Bisoprolol & 29 & $7.0 \%$ \\
\hline Mual & $\begin{array}{l}\text { - Bisoprolol, Candesartan, } \\
\text { Lisinorpil, Ramipril }\end{array}$ & 28 & $6.7 \%$ \\
\hline Gangguan tidur & - Bisoprolol & 27 & $6.5 \%$ \\
\hline Hiponatremia & - Furosemid & 19 & $4.6 \%$ \\
\hline Muntah & - Digoxin & 16 & $3.8 \%$ \\
\hline Gatal & $\begin{array}{l}\text { - Spironolakton, Captopril, } \\
\text { Furosemid, Bisoprolol }\end{array}$ & 15 & $3.6 \%$ \\
\hline
\end{tabular}

Analisis kausalitas adalah proses evaluasi yang dilakukan untuk menentukan atau menegakkan hubungan kausal antara kejadian efek samping yang terjadi atau teramati 
dengan penggunaan obat oleh pasien (BPOM RI, 2012). Penentuan suatu kejadian klinis merupakan hal yang tidak mudah, sebab diperlukan pengkajian yang lebih untuk menentukan apakah kejadian yang terjadi merupakan ADRs atau karena penurunan kondisi primer dari pasien. Jika hal tersebut adalah ADRs, maka perlu mengetahui jenis obat apa yang menyebabkannya, karena tidak jarang pasien $\mathrm{CHF}$ menggunakan beberapa macam obat secara bersamaan ketika sakit, terutama jika menjalani perawatan di rumah sakit.

Hasil penilaian kausalitas ADRs menggunakan skala WHO-UMC (Tabel 2) menunjukkan status angka kejadian ADRs adalah 8 (1,8\%) certain, 178 (39,9\%) probable/likely, dan $260(58,3 \%)$ possible. Target pelaporan dan program pemantauan ADRs ini adalah untuk mengidentifikasi dan mengukur risiko yang terkait dengan penggunaan obat sebagai upaya mempromosikan penggunaan obat secara rasional. Keterlibatan apoteker dalam perawatan pasien bisa membantu dalam pencegahan dan deteksi dini ADRs (Ponnusankar et al., 2015).

\section{Peningkatan kreatinin}

Peningkatan kreatinin terjadi pada 66 (15,9\%) Kasus. Obat-obatan yang dicurigai dapat meningkatkan kadar kreatinin pada penelitian ini yaitu golongan diuretik seperti furosemid dan spironolakton, obat golongan Angiotensin reseptor blocker (ARB) seperti valsartan dan candesartan serta obat golongan ACE-inhibitor contoh obatnya yaitu Ramipril dan Lisinopril. Pemakaian Valsartan dan Lisinopril dapat meningkatkan serum kreatinin dan BUN. Pemberian awal ACE-inhibitor atau Angiotensi Reseptor blocker (ARB) dapat terjadi peningkatan serum kreatinin $<30 \%$ di atas baseline (Anita , 2014).

Hasil Penelitian yang dilaporkan oleh Mateti et al (2012) di salah satu Rumah sakit di Selatan India, peningkatan serum kreatinin pada awal pemberian ACE-inhibitor dan ARB sebanyak $25 \%$ dari diatas baseline dan setelah 18 bulan pemakaian ACEi atau ARB insiden hiperkreatinemia terjadi sebesar 10,5\%. ACEi/ARB dapat digunakan dengan hatihati, obat golongan ini memperbaiki kondisi gagal jantung tetapi pada gagal ginjal dapat memperburuk fungsinya, $\mathrm{ACE}$ / $\mathrm{ARB}$ dapat meningkatkan vasodilatasi di eferen.

\section{Batuk}

Pada penilaian kausalitas dalam penelitian ini, batuk merupakan ADRs yang termasuk dalam kategori certain dengan frekuensi kejadian paling banyak. Batuk kering serta persisten merupakan efek samping obat golongan ACE-I, dan telah dilaporkan insidensi batuk terkait ACE-I tersebut berada di kisaran 5\% sampai 35\% (Dicpinigaitis, 2006), sedangkan penelitian lain di Polandia menunjukkan bahwa batuk terkait ramipril terjadi pada 7,1\% pasien (Wyskida, Jura-Szołtys, Smertka, Owczarek, \& Chudek, 2012). Batuk yang diinduksi ACE-I hanya terjadi pada individu yang rentan dan tidak berhubungan dengan dosis obat. Oleh karena itu, ini adalah reaksi idiosinkratik (Y1lmaz, 2019).

Efek samping seringkali terjadi secara spesifik untuk golongan obat tertentu dan tergantung pada mekanisme kerjanya. Karena alasan ini, setiap efek samping suatu obat ACE-I juga dapat terjadi dengan penggunaan dari ACE-I lainnya (Y1lmaz, 2019). Dalam sebuah studi kohort, 19\% pasien yang menggunakan ACE-I telah terbukti menghentikan pengobatan mereka karena efek samping (kebanyakan batuk yang terjadi secara terusmenerus) (Morimoto MPH et al., 2004). Batuk karena obat-obatan ini bisa berkurang dalam 1 hingga 4 minggu setelah penghentian, tetapi dalam beberapa kasus, ini bisa memakan waktu hingga 3 bulan (Dicpinigaitis, 2006). Bahkan, jika semakin lama batuk terjadi selama pengobatan, maka batuk juga cenderung tidak hilang setelah penghentian Ramipril (Wyskida et al., 2012). 
Mekanisme batuk akibat ACE-I masih belum jelas. Mediator yang mungkin berperan dalam berkembangnya batuk terkait ACE-I adalah bradikinin dan substansi $\mathrm{P}$, yang seharusnya dihancurkan oleh ACE. Jadi, melalui penghambatan enzim ini oleh ACE-I maka bradikinin dan substansi $P$ terakumulasi di saluran pernafasan atas dan bawah. Bradykinin juga merangsang prostaglandin (Fox et al., 1996; Israili \& Dallas Hall, 1992). Namun, berdasarkan hasil dari berbagai penelitian menunjukkan bahwa kemungkinan tidak hanya ada satu mekanisme yang bertanggung jawab terjadinya batuk yang diinduksi oleh ACE-I. Hal ini dapat disebabkan oleh kombinasi dari dua atau lebih mekanisme, antara lain dengan bronchial hyperreactivity (BHR), riwayat asma, $\mathrm{CHF}$, peningkatan sensitivitas serat saraf sensorik saluran napas yang bergantung pada bradikinin, polimorfisme gen reseptor bradikinin, peningkatan sensitivitas refleks batuk, defisiensi enzim aminopeptidase $\mathrm{P}$ (APP) dalam pemecahan bradikinin, dan mekanisme yang mencakup polimorfisme penyisipan/penghapusan ACE. (Y1lmaz, 2019).

\section{Hipotensi}

Pada hasil sebuah penelitian mengenai monitoring dan pelaporan ADRs yang disebabkan oleh obat kardiovaskuler juga menunjukkan bahwa kelas obat yang paling banyak menyebabkan ADRs adalah $\beta$-bloker terutama bisoprolol (14.68\%) dan mayoritas pasien mengalami bradikardia (10.09\%) dan hipotensi (8.26\%) (Wadhwa et al., 2018).

\section{Pusing}

Pusing terjadi pada 61 (14.7\%) Kasus, obat yang dicurigai menimbulkan reaksi adverse drug reactions yaitu golongan ACE-inhibitor (Lisinopril dan Ramipril), obat golongan B-Blocker (Bisoprolol) dan golongan ARB seperti Valsartan. Hasil penelitian yang dilaporkan oleh Sangole et al (2010) Prevalensi ADRs berupa Pusing sebanyak 11 (36\%) kasus dan merupakan laporan ADRs tertinggi yang dikeluhkan oleh pasien rawat inap, obat yang di curigai dapat menyebabkan pusing menurut penelitian tersebut adalah Ramipril dan Lisinopril.

\section{Mual}

Kejadian Adverse drug reactions (ADRs) Gangguan gastrointestinal merupakan gejala ADRs yang relatif umum yang muncul pada pasien yang mendapatkan terapi obat Congestive heart failure (CHF), hasil penelitian menunjukkan sebanyak 28 (6.7\%) pasien mengalami gejala gangguan gastrointestinal seperti mual. Prevalensi mual yang dilaporkan oleh Sangole et al (2010) sebanyak 10\% dari total keseluruhan ADRs yang terjadi, obat lisinopril, enalapril dan ramipril lebih tinggi menyebabkan ADRs mual dibandingkan obat golongan lain. Hasil penelitian yang dilaporkan Mohebbi, Shalviri, Salarifar, Salamzadeh, \& Gholami, (2010) dalam penelitiannya di salah satu rumah sakit di Iran dimana persentase kejadian ADRs lebih besar terjadi pada gastrointestinal setelah pemberian obat-obatan CHF, ini disebabkan terapi obat lebih dari satu yang dapat menjadi faktor gangguan gastrointestinal. ADRs Gastrointestinal dapat disebabkan oleh penggunaan obat Bisoprolol, candesartan, lisinopril dan ramipril yang diresepkan kepada pasien, pada umumnya, gangguan gastrointestinal merupakan ADRs ringan tetapi bisa menjadi cukup berat dan membutuhkan penyesuaian terapi.

\section{Nyeri Perut}

Nyeri Perut merupakan Adverse drug reaction terbanyak ke empat setelah peningkatan kreatinin, Batuk dan Pusing, Pasien yang mengalami nyeri perut sebanyak 34 (8.2\%) Kasus, obat yang dapat menyebabkan nyeri perut pada penelitian ini seperti golongan 
ACE-inhibitor, golongan diuretik dan obat golongan B-blocker. Hasil sebuah penelitian mengenai monitoring dan pelaporan ADRs yang disebabkan oleh obat kardiovaskuler juga menunjukkan bahwa kelas obat yang paling banyak menyebabkan ADRs adalah ACEi terutama lisinopril dan Ramipril. Mateti et al (2012) melakukan penelitian di salah satu Rumah sakit di India, hasil yang didapatkan bahwa insiden ADRs berupa nyeri perut sebanyak $23(38,33 \%)$ pasien, obat yang diduga menjadi penyebab keluhan pasien tertinggi yaitu golongan ACEi seperti lisinopril.

\section{KESIMPULAN}

Hasil penelitian ini menunjukkan bahwa obat yang digunakan pasien $\mathrm{CHF}$ dapat menyebabkan reaksi yang merugikan mulai dari yang ringan hingga sedang dan sering terjadi. Pada penelitian ini obat yang termasuk dalam kategori highly probable dalam menyebabkan ADRs pasien CHF adalah bisoprolol dan Ramipril, oleh karena itu pemantauan $\mathrm{ADR}$ s pada pasien $\mathrm{CHF}$ adalah yang penting terutama untuk mencapai hasil terapi yang optimal dan mencegah potensi timbuknya ADRs yang lebih parah.

\section{REKOMENDASI}

Faktor resiko seperti jenis kelamin, usia, dan ada tidaknya penyakit komorbiditas tidak menunjukkan hubungan yang signifikan pada timbulnya ADRs. Oleh karena itu untuk membutktikan signifikasi hubungan tersebut dan menghasilkan data yang lebih kompleks maka perlu dilakukan penelitian lebih lanjut dengan jumlah sampel yang lebih banyak dan metode penelitian yang berbeda.

\section{UCAPAN TERIMA KASIH}

Terimakasih kami ucapkan kepada semua civitas akademika Universitas Qamarul Huda Bagu atas dukungannya sehingga penelitian ini dapat terlaksana. Tidak lupa pula kami sampaikan terimakasih kepada semua informan RSUD Provinsi NTB atas kerjasama dan informasi yang diberikan selama penelitian ini berlangsung.

\section{DAFTAR PUSTAKA}

Alomar, M. J. 2014. Factors affecting the development of adverse drug reactions (Review article). Saudi Pharmaceutical Journal, 22(2).

BPOM RI. 2011. Peraturan Badan pengawas Obat dan Makanan Republik Indonesia Tentang Penerapan Farmakovigilans Bagi Industri Farmasi. , Badan Pengawas Obat dan Makanan.

BPOM RI. 2012. Pedoman Monioring Efek Samping Obat (MESO) Bagi Tenaga Kesehatan. Direktorat Pengawasan Distribusi Produk Terapetik Dan PKRT Badan Pom RI, $1-35$.

Dicpinigaitis, P. V. 2006. Angiotensin-Converting Enzyme Inhibitor-Induced Cough, ACCP Evidence-based Clinical Practice Guidelines. Chest Journal, 129(1).

Fox, A. J., Lalloo, U. G., Belvisi, M. G., Bernareggi, M., Chung, K. F., \& Barnes, P. J. 1996. Bradykinin-evoked sensitization of airway sensory nerves: A mechanism for ACE-inhibitor cough. Nature Medicine, 2(7)

Israili, Z. H., \& Dallas Hall, W. 1992. Cough and angioneurotic edema associated with angiotensin-converting enzyme inhibitor therapy: A review of the literature and pathophysiology. Annals of Internal Medicine, 117(3).

Kemenkes.RI. 2016. Profil Penyakit Tidak Menular Tahun 2016. Jakarta.

Mehta, P. A., \& Cowie, M. R. 2006. Gender and heart failure: A population perspective. Heart, 92(SUPPL. 3). 
Morimoto MPH, T., Gandhi MPH, T. K., Fiskio BS, J. M., Seger PharmD, A. C., So BS, J. W., Francis Cook ScD, E., ... Bates DW. 2004. An evaluation of risk factors for adverse drug events associated with angiotensin-converting enzyme inhibitors. Journal of Evaluation in Clinical Practice, 10(4).

PERKI. 2015. Pedoman Tatalaksana Gagal Jantung. In Pedoman Tatalaksana Gagal Jantung (Pertama). PERHIMPUNAN DOKTER SPESIALIS KARDIOVASKULAR INDONESIA.

Ponnusankar, S., Tejaswini, M., \& Chaitanya, M. 2015. Assessment of adverse drug reactions based on spontaneous signals at secondary care public hospital. Indian Journal of Pharmaceutical Sciences, 77(4).

Razzolini, R., \& Lin, C. D. 2015. Gender diff erences in heart failure. Ital J Gender-Specifi Med.

Wadhwa, T., E1 Sheikh, S. G., \& Rao, P. G. M. 2018. Monitoring and Reporting of Adverse Drug Reactions Due to Cardiovascular Drugs in Patients Admitted to a Secondary Care Hospital in Northern Emirate- a Prospective Surveillance Study. Indian Journal of Pharmacy Practice, 11(2).

Wankhede, S. Y., Pardeshi, M. L., Ghorpade, V. V, \& Ghongane, B. B. 2018. An assessment of pattern of adverse drug reactions of cardiovascular drugs in a tertiary care institute. IJBCP: International Journal of Basic \& Clinical Pharmacology, 7(2).

Wells, B. G., Dipiro, J. T., Schwinghammer, T. L., \& Dipiro, C. V. 2015. Heart Failure. In Pharmacotherapy Handbook (9th ed.). MC Graw Hill Education.

Wyskida, K., Jura-Szołtys, E., Smertka, M., Owczarek, A., \& Chudek, J. 2012. Factors that favor the occurrence of cough in patients treated with ramipril - A pharmacoepidemiological study. Medical Science Monitor, 18(9).

Y1lmaz, İ. 2019. Angiotensin-converting enzyme inhibitors induce cough. Turkish Thoracic Journal, 20(1). 